\title{
ИСТОРИЯ «ЗАПАДНОЙ РОССИИ» В СОЧИНЕНИЯХ А.Д. СТОЛЫПИНА
}

Комзолова Анна Альфредисовна

\section{HISTORY OF THE "WESTERN RUSSIA" IN THE WRITINGS OF A.D. STOLYPIN ${ }^{2}$}

\section{A. Komzolova}

Summary: The article considers views of A.D. Stolypin (1822-1899), father of the reformer P.A. Stolypin, on the Polish question, the history of Lithuania and the historical ties between the Russian state and Lithuanians. Interested in the history of the lands of the former Grand Duchy of Lithuania while serving in Vilna in the 1860s., A.D. Stolypin became the author of several historical works, as well as a play "Sofia". Following the historical concept of N.G. Ustrialov and recognizing the division of Rus' into two parts - eastern and western, «Lithuanian», in the XIII century, A.D. Stolypin sought to prove the "primordial Russianness» of this region. The idea of the common Russian-Lithuanian historical heritage was justified by the notion of continuity in the statehood of the Kievan Rus', the Grand Duchy of Lithuania and the Russian empire.

Keywords: Lithuania, Belarus, North-Western Provinces, A.D. Stolypin, M.N. Muraviov, historical memory.
A ркадий Дмитриевич Столыпин (1822-1899) принадлежит к числу тех личностей, которые привлекают внимание историков не столько в силу собственных заслуг и талантов, сколько благодаря родственным и дружеским связям, соединявшим их с более значительными и заметными фигурами. Аркадий Дмитриевич известен, прежде всего, как отец Петра Столыпина и как друг Л.Н. Толстого. Биография А.Д. Столыпина во многом схожа с биографиями других представителей его круга и его поколения. Получив домашнее образование, он в 1838 г. поступил на военную службу. Ветеран Венгерского похода 1849 г. и Крымской войны 1853-1856 гг., Столыпин отличился при обороне Севастополя, за участие в боевых действиях награжден золотым оружием с надписью «За храбрость», а также орденами Св. Анны 1-й степени с мечами и короной, Св. Владимира 4-й, 3-й и 2-й степеней с мечами, Белого Орла с мечами. Во время русско-турецкой войны 1877-1878 гг. он состоял в распоряжении главнокомандующего действующей армии, был комендантом крепости Никополь, а затем г. Плевно. В 1878 г. Столыпин участвовал в устройстве гражданского управления в Болгарии, был генерал-губернатором Восточной Румелии и Адрианопольского Санджака. По окончании войны он командовал 9-м армейским корпусом, в 1886-1889 гг. в чине генерала от артиллерии - Гренадерским корпусом, затем был назначен членом Александровского комитета о раненых. В 1892 г. Столыпин был произведен в обер-камергеры и до конца жизни заведовал Дворцовой частью в Москве. Одновременно он возглавлял Московское филармоническое общество, Российское общество сельскохозяйственного птицеводства, был членом Императорского Московского скакового общества [16]. Человек творчески одаренный, Столыпин увлекался скульптурой и музыкой, писал стихи, пьесы, исторические и публицистические сочинения. Ему принадлежит несколько музыкальных композиций, а некоторые его скульптурные произведения демонстрировались на академических выставках.

Исследование выполнено в рамках гранта № 19-18-00073 «Национальная идентичность в имперской политике памяти: история Великого княжества Литовского и Польско-Литовского государства в историографии и общественной мысли XIX - XX вв.» Российского научного фонда.

2 This research was supported by the grant No 19-18-00073 "National Identity in the Imperial Politics of Memory: History of The Grand Duchy of Lithuania and the Polish-Lithuanian State in Historiography and Social Thought of the 19th - 20th Centuries" of the Russian Science Foundation. 
Внучка Столыпина так вспоминала о его творческих увлечениях: «Одна из комнат была музыкальным салоном. Дедушка, будучи хорошим музыкантом, с увлечением играл на своем Страдиваурисе, сам писал музыку и раз у себя дома поставил целую оперу, “Норму”, прошедшую с большим успехом. Была у него и студия, где он занимался скульптурой и часто подолгу там работал» [1, с. 21]. Хотя Столыпин не достиг вершин ни в одном из выбранных им занятий, оставаясь дилетантом, он всегда занимал прочное положение в обществе и последовательно поднимался по служебной лестнице.

Особый интерес Столыпина к истории «Западной России» - земель бывшего Великого княжества Литовского - появился под влиянием широкого патриотического подъема в русском обществе, возникшего в связи с началом польского восстания 1863-1864 гг. и угрозой внешнего вмешательства европейских держав. Весной 1864 г. Столыпин приехал в Северо-Западный край в качестве офицера, состоявшего в распоряжении командующего войсками Виленского военного округа. По признанию самого Столыпина, до приезда в новый для него край он изучал его у себя дома, в кабинете. В Вильне он нашел единомышленников среди служивших там русских чиновников и военных - в кругу читателей газеты «День» И.С. Аксакова, близких к славянофилам. Столыпин вслед за многими представителями интеллигенции полагал, что благодаря польскому восстанию произошел определенный перелом в сознании русского общества, у которого «открылись глаза» на ополячивание западных губерний. Деятельность Виленского генерал-губернатора М.Н. Муравьева (1863-1865 гг.) способствовала тому, что в России окрепло убеждение в «русскости» Западного края. «Благодаря ему и той полемике, которая возникла вследствие его системы действия, - отмечал Столыпин, - открылись глаза: мы с ужасом увидели, что целые общества, бывшие некогда православными, еще в недавнее время обращались в католицизм». Как полагал Столыпин в середине 1860-х годов, начатое при Муравьеве «обрусение» Западного края не должно было стать «вековой работой», а, напротив, его следовало форсировать в ближайшее время. Размышляя о возможности изменить край «в три года», он писал: «Несмотря на вековую работу, поляки не в состоянии были совершенно ополячить западный русский край: не есть ли это новое доказательство преобладания русского элемента в этой несчастной стране? <...> Века, века! Это говорят поляки и ослепленные ими полонофилы. Они хотят заставить нас взяться за медленную вековую работу, зная, что мы к ней не способны, что мы, угомонившись опять, по добродушию своему, запутаемся в польских сетях, хотят отклонить нас от настойчивого, скорого труда, присущего русской натуре» [12, с. 215, 217, 227-228]. В 1866 г. Столыпин, подобно Ф.И. Тютчеву [18], откликнулся на кончину М.Н. Муравьева публикацией стихотворения. Он заканчивал его такими строчками: «...Лишь умер смертный человек, / Лишь смертного теперь не стало. / Бессмертный же останется вовек / Здесь, на Литве, как русское начало!» [13]

При генерал-губернаторах М.Н. Муравьеве и К.П. Кауфмане Столыпин занимал видное место в Виленской администрации. В 1865-1866 гг. он возглавлял Комиссию «для рассмотрения польских и жмудских книг», в задачи которой входили проверки местных типографий и книжных складов, экспертиза различных светских и религиозных изданий на польском и литовском языках, а также расследование деятельности Виленского цензурного комитета [20, s. 94, 95, 102-106]. Помимо этого, Столыпин был членом, а затем и председателем особой комиссии, занимавшейся реорганизацией Виленского музея древностей (ныне Национальный музей Литвы). Комиссии следовало разобрать экспонаты и экспозицию музея согласно новой концепции: избавившись от прежнего увлечения «польской исключительностью», преобразованный музей призван был напоминать посетителям об «искони господствующих в здешнем крае» «русской народности» и православии [8, с. 263-269, 276-282; 9, с. 105-114]. Столыпин придавал большое значение просветительской миссии Виленского музея, его роли в патриотическом воспитании местных жителей, а основную цель работы комиссии видел в том, чтобы восстановить «историческую истину» с помощью «чистой науки», оставив в стороне «политические прения». По его мнению, музей должен был поддерживать и укреплять как монархические чувства, так и «сознание кровного родства Западного края с остальной Россией». В частности, Столыпин считал возможным сохранить в экспозиции памятники, «относящиеся до литовско-русского боярства», отделив их от «чисто польских». Он также предлагал дополнить музейную витрину, посвященную эпохе 1812 г., предметами, напоминавшими об императоре Александре I и его сподвижниках, и наряду с этим вообще расширить в экспозиции присутствие российских императоров: «и пыль с сапог наших царей для Виленского музея была бы драгоценностью» [6, с. 1-6, 11-13, 53-58, 64-67; 8, с. 273-274]. На рубеже 1860-1870-х годов Столыпин также принимал участие в деятельности Северо-Западного отдела Императорского Русского географического общества [20, s. 99-100].

Находясь в Северо-Западном крае, Столыпин начал собирать материалы по истории Литвы. В 1860-х гг. он написал несколько работ для народного просвещения, включая «Историческую таблицу Северо-западной части Российской империи, занимаемой губерниями: Виленской, Ковенской и Гродненской» (1864 г.) и брошюру «Краткая история России для народного и солдатского чтения» (1869 г.), кроме того, опубликовал отрывки «Хроники Генриха Латыша» со своими комментариями (1867 г.). Столыпин также был автором пьесы «София», поставленной в 1866 г. в Вильне на театральной сцене. 
Все эти сочинения, за исключением «Краткой истории России», Столыпин опубликовал не под своей фамилией, а подписывал двумя ее первыми буквами «Ст...». То, что авторство этих работ принадлежит Столыпину, подтверждается заметкой, опубликованной в «Виленском вестнике» в январе 1866 г. В этой газетной публикации сообщалось о предстоявшей постановке на Виленской сцене пьесы «София». В заметке указывалось, что эта пьеса была написана «автором “Писем из Северо-Западного края", “Исторической таблицы” и других литературных и ученых работ, пишущим под псевдонимом Ст...» [19]. Как достоверно известно, автором пьесы «София» был именно Столыпин. Еще в начале XX в. К.А. Военский опубликовал отзыв на эту пьесу писателя И.А. Гончарова, в качестве цензора и члена Главного управления по делам печати [2, с. 615-619].

В пьесе «София» (1866 г.) Столыпин обращается к событиям недавнего прошлого - польскому восстанию 1863-1864 гг. на землях бывшего Великого княжества Литовского. Согласно воспоминаниям современника, пьеса Столыпина «шла несколько раз в Виленском театре и имела успех. Особенно нравилось публике пение последних слов» [3, с. 609]. Пьеса заканчивалась стихотворными строчками: «Литва и Белая Россия не будут Польшей никогда!» $[10$, л. 60]. Основой ее сюжета становится «польская интрига» накануне и во время восстания, а одним из главных героев представлен «Незнакомец»приехавший из-за границы польский эмиссар, посланец Варшавского революционного комитета, который пытается втянуть в мятеж помещиков Литвы. Эмиссар раздает им польские газеты и герценский «Колокол», сулит военную помощь Западной Европы: «Швеция по примеру Англии вооружает свой флот, и Гарибальди уже двинулся со значительной армией». Автор обличает двуличие и лживость «Незнакомца»: это барин и аристократ, но в русском обществе выдает себя за русского чиновника, называет себя «гражданином земли русской», «руссопётой» и публично признается в любви к мужику. В кругу русских офицеров он одет «в изящный костюм хлопомана», чтобы, по его словам, «побесить» местных польских панов, а среди поляков - в «черную чемарку и конфедератку». В духе лозунга «за нашу и вашу свободу» эмиссар пытается агитировать русских офицеров, убеждая их в случае вооруженного столкновения не применять оружие и не стрелять «в свой народ - в меньшую братью», на что сразу получает отповедь о необходимости стрелять по бунтовщикам [10, л. 2, 27-28, 35-38 об.].

Дочь местного помещика Зданишевского Софья, узнав о польском заговоре, сообщает о замыслах «довудцев» своему жениху Холмогорову, офицеру гусарского эскадрона. Поляки пытаются повесить Софью как предательницу, на шею ей уже накинута петля, но ее спасает жених со своими гусарами [10, л. 57-59]. Столыпин, стремясь преодолеть очевидный схематизм сюжета, наделил «титульную» героиню пьесы Софью двойной идентичностью. «Восторженная от деревенского уединения», но «с мужским складом ума», эта молодая девушка, по словам автора, «с теплой душой от постоянного соприкосновения с добрым белорусским народом» $[10$, л. 2]. Хотя Софья выросла в семье отца-католика и ходит в костел, но ее покойная мать, а также и белорусская няня - православные, и в раннем детстве ее водили в православную церковь. Наконец, устами ее жениха, русского офицера, автор формулирует отношение к идентичности, как самой Софьи, так и вообще местных помещиков: «Поляки [живут] в Польше, а в России, Западная она или Восточная, все должны быть русские; хорошие эти русские или нет?... это другой вопрос!» [10, л. 34 об.].

Пожалуй, наиболее симпатичным героем пьесы является полковой доктор Абрамзон, проникнутый русской культурой еврей, по словам автора, «образованный и не гнушающийся своего происхождения». Проницательный доктор ранее других заподозрил в «Незнакомце» польского революционного агента, но в конце пьесы он проявляет милосердие и спасает раненого эмиссара от расправы русских солдат. От лица доктора Столыпин, очевидно, провозглашает и собственное отношение к возможности решения еврейского вопроса посредством просвещения: «Есть евреи и евреи - на одних можно надеяться, на других - нет. Есть евреи, которые чуждаются всякого образования, которые находятся под гнетом предрассудков и ложных преданий, которые, между тем как другие народы развивались и шли вперед, упорно оставались, и до сих пор остаются, на той же степени образования, на которой были во времена странствования по пустыни. Эти евреи теперь, как и тогда в пустыне, не Богу поклоняются, а золотому тельцу <...>. Есть евреи, которые стыдятся своего происхождения, которые в своем отечестве в России, спекулируя на русское гостеприимство, стараются прослыть за иностранцев, за немцев, у этих евреев нет отечества <...>. Но есть евреи, которые стремятся ко всепознанию, которые жаждут науки, вместе с тем не только не скрывают, но гордятся происхождением своим от рода, к которому принадлежали первые пророки человечества; Россию, которая, как чадам своим, так широко открыла им двери, они считают матерью-отчизной, а Царя, который дарует им свободы наравне с другими своими подданными, вместе с ними, они чтут освободителем и учат детей своих молиться за него! Таким евреям вы можете верить, вы можете назвать их русскими, назвать их братьями!» [10, л. 3, 32, 38-40 об., 54, 55].

Характерно, что И.А. Гончаров как цензор этой пьесы высказывался против ее постановки на театральной сцене в Вильне. По его мнению, поскольку поляки в ней преимущественно изображались довольно карикатурно, как трусы, глупцы и продажные негодяи, было крайне сомнительно, что такая постановка могла спо- 
собствовать укреплению в Северо-Западном крае русского влияния. Историческая память об этом недавнем прошлом у русских и поляков радикально различалась. «Действительно, нам, русским, - писал Гончаров, - трудно, да и не хочется представлять поляков иначе, как такими, какими они представлены в драме "Софья": но это наш, русский патриотический взгляд, взгляд победителей, и притом убежденных в правоте своего дела». Он опасался, что местные зрители - «из поляков, а может быть и не из поляков» - найдут в пьесе много искажений и преувеличений: они «приведут примеры вешателей и убийц, зверски-фанатических, погибших позорною, а с их точки зрения - геройскою смертью, укажут множество людей, обманутых и увлеченных, но отдавших все состояние на восстание, приведут примеры отчаянной отваги безумной и доверчивой молодежи - и таким образом опрокинут добрую цель пьесы, представив ее умышленным сокрытием истины, или односторонним, случайно взятым исключением». Вместе с тем сам Гончаров, в отличие от Столыпина, видимо, не считал СевероЗападный край «Западной Россией», и не усматривал там «преобладания» русских, отмечая, что в этом крае «численностью преобладают поляки, потом евреи, русские составляют меньшинство» $[2$, с. 617,618$]$.

Исторические сочинения Столыпина, написанные специально для целей народного образования, вероятно, использовались как учебные материалы в начальных и средних учебных заведениях. В частности, экземпляры «Исторической таблицы» Столыпина были развешаны в классах Виленского раввинского училища и использовались в качестве наглядного пособия на уроках русской истории. Но, как отмечал рецензент - чиновник Виленского учебного округа, «Историческая таблица» для того, чтобы действительно стать чтением для народа, должна была быть написана более доступным и понятным языком, между тем как автор ориентировался не столько на аудиторию народных школ, сколько вообще на всех интересующихся историей края [17]. В 1860-х годах, в то время, когда публиковались научно-популярные брошюры Столыпина, с одной стороны, наблюдался рост наименований и тиражей учебной литературы, а с другой, практически отсутствовали не только доступные для народа учебники по литовско-русской истории, но и основательные академические издания.

Необходимость изучения литовско-русской истории Столыпин связывал с необходимостью выработать идеологическое обоснование политики русификации этого края. «Если бы мы, - писал он, - не имели ясных доказательств в русском происхождении князей, именуемых литовскими, и не менее ясных данных, что во владении этих князей литовское племя занимало лишь ничтожную часть оного, то фраза, на которой зиждется вся русская политика в Северо-Западном крае, что этот край есть искони русское достояние, была бы бессмыслицей» [14].
Историческая концепция, представленная в сочинениях Столыпина, в целом следовала общей схеме, разработанной историком Н.Г. Устряловым в 1830-1840-х годах. Столыпин выделял в историческом развитии России два ключевых момента. Во-первых, это разделение («раздвоение») Руси в XIII в. под влиянием татарского нашествия на две части - восточную, «Московскую Русь» и западную, «Литовскую Русь». А во-вторых, это соединение в конце XVIII в. при императрице Екатерине II обеих частей Руси «воедино». Два этих ключевых события делили историю России на три основных этапа: 1) до разделения Руси - общерусская история; 2) с XIII В. до конца XVIII в. - параллельная история «Западной Литовской» Руси и Руси «Восточной Московской»; 3) с конца XVIII в. история «всероссийская» $[11 ; 15$, с. 48, 49, 53].

Как для Устрялова, так и для Столыпина исходным пунктом в русско-литовской истории было представление об отсутствии у Литвы собственной самобытной государственности. Однако в тех вопросах, где Устрялов, историк профессиональный, только намечал мысль, лишь указывал ее контуры, Столыпин ее акцентировал и доводил до логического конца. В частности, Столыпин утверждал, что у литовцев никогда не было ни «высшего слоя общества, интеллигенции», ни своей письменности, ни даже собственных народных песен - все это они заимствовали у русских или поляков. Это предполагаемое отсутствие практик цивилизованности у литовцев Столыпин определял термином «аборигенность» [14]. Он был склонен рассматривать «аборигенность» литовцев скорее в негативном смысле, используя это выражение как синоним отсталости и дикости. В этом вопросе Столыпин наиболее существенно расходился с современными ему публицистами и историками славянофильского направления, прежде всего с А.Ф. Гильфердингом, который признавал, что у литовцев когда-то существовала собственная государственность, а в архаичных чертах их языка и быта усматривал народную самобытность литовцев [4].

Стремясь как можно более веско и убедительно доказать «исконную русскость» Северо-Западного края, Столыпин использовал, пожалуй, все имевшиеся в то время в распоряжении русских историков и публицистов аргументы. Так, он считал, что «ядром» будущего «Литовско-Русского Великого княжества» было Полоцкое княжество. Также по его словам, собственно литовцы, или Литва этническая, занимали в русско-литовском государстве «лишь незначительную часть территории»ту же самую, которую они занимали в XIX в. в рамках Российской империи, т.е. Ковенскую губернию и часть Виленской губернии. По его мнению, было бы ошибкой называть Северо-Западный край «не только польским, но даже и литовским» $[12$, с. 226; 14]. Также Столыпин считал «правдоподобной» теорию о славянском происхождении литовцев. Эта теория, весьма влиятельная в XVIII в. и начале XIX в., т.е. до развития сравнительного 
языкознания, предполагала, что балтийские языки произошли от славянских, и опиралась в этом выводе на простое сопоставление лексических элементов этих двух языковых групп [5, с. 152-153; 7]. Столыпин, не будучи лингвистом, считал, что «в литовское наречие входит $3 / 4$ слов славянских» [11]. Кроме того, он считал, что литовские князья были «литовскими» только по названию, но не были этническими литовцами. В этих выводах Столыпин пошел значительно дальше Устрялова. Согласно Устрялову, литовские князья, хотя и не являясь потомками Владимира Святого, были очень тесно связаны с русскими князьями родственными узами. Эти князья-язычники утвердили свою власть в «Западной Руси» с помощью постоянных браков, заключавшихся с дочерьми русских князей, православными по вероисповеданию. Как полагал Столыпин, литовские князья либо прямо происходили от Рюрика и его потомков, либо от какого-либо из князей - «варяго-руссов». «Если бы они были коренные литовцы, - рассуждал он, - то создали бы грамотность и цивилизацию литовскую», в то время как на деле они «внесли с собой в Литву язык и обычаи русские». Наиболее вероятным Столыпин считал происхождение литовских князей из полоцкого княжеского рода. С его точки зрения, эти князья бежали в Литву, спасаясь от междоусобиц. Осев в Литве, они из православия перешли в язычество, чтобы заручиться поддержкой местного языческого населения. Но как только необходимость в этом отпала, эти князья вновь перешли в православие. При этом особую роль Столыпин отводил браку князя Ольгерда с Юлианией Витебской и его переходу в православие. Он подчеркивал, что православная вера пришла в Литву ранее католичества, что само по себе, по его мнению, было важным доказательством русско-литовского исторического единства $[11 ; 15$, с. 56-59].

Наконец, и это было, пожалуй, наиболее оригинальным в его концепции, Столыпин приходил к заключению, что, на основании династического принципа, литовцев из Вильны можно называть «русскими» с не меньшим основанием, чем, например, славян из Москвы или «чухонцев» из Петербурга [15, с. 24]. Обосновывая свою точку зрения, он писал: «Обширное пространство, занимаемое ныне Российской империей, в старину не называлось Россией, а народы, обитавшие в ней, не назывались русскими; они принадлежали к различным племенам, которые происходили от корней: славянского, финского, туркского и др. Приняли они название русских от князей варяго-русских, которых они впоследствии вызвали на княжение, и поэтому все они с тех пор имеют одинаковое право на название русских, каковое одинаковое право с тех пор имеет каждая часть Российского государства» [11].

Таким образом, работы Столыпина представляют интерес прежде всего как своеобразный «слепок» исторического сознания представителя как русского образованного общества, так и интеллигентного чиновничества. Вместе с тем при оценке этих сочинений необходимо также принимать во внимание творческую индивидуальность автора. Историческая концепция Столыпина соединила государственно-династическую теорию, предполагавшую целостность всех частей России под властью самодержца - будь то Рюриковичи или Романовы, с идеями об этнолингвистической общности русского народа.

\section{ЛИТЕРАТУРА}

1. Бок М. П.А. Столыпин: Воспоминания о моем отце. М.: Современник, 1992. 316 с.

2. Военский К. Гончаров-цензор: Неизданные материалы для его биографии // Русский вестник. 1906. № 10. С. 571-619.

3. Гене А. Виленские воспоминания // Русская старина. 1914. № 6. С. 580-610.

4. Гильфердинг А.Ф. Несколько замечаний о Литовском и Жмудском племени // День. 1864. № 8. 22 февраля. С. 9-15.

5. Дини П.У. Балтийские языки / Пер. с итал. М.: ОГИ, 2002. 543 с.

6. Дневник заседаний Комиссии для разбора и приведения в известность и надлежащий порядок предметов, находящихся в Виленском музеуме древностей (из «Вестника западной России»). Вильна: В типографии Р.М. Ромма, 1865. 74 с.

7. Комзолова А.А. В поисках родства: происхождение литовцев в российской политической и исторической мысли, 1820-1860-е гг. // Современная наука: актуальные проблемы теории и практики. Серия: Гуманитарные науки. 2019. № 11/2. С. 18-24.

8. Котов А.Э. «В крепких руках правительства»: письма И.П. Корнилова и А.Д. Столыпина о преобразовании Виленского музея древностей // Вопросы музеологии. 2019. Т. 10. № 2. С. 263-282.

9. Котов А.Э. Русский политический предмодерн: забытые «консерваторы» второй половины XIX века. СПб.: Владимир Даль, 2019. 285 с.

10. Российский государственный исторический архив. Ф. 1662. Оп. 1. Д. 262.

11. [Столыпин А.Д.] Историческая таблица Северо-западной части Российской империи, занимаемой губерниями: Виленской, Ковенской и Гродненской. [2-е изд.]. Вильна: Типография А. Сыркина, 1864. [Без нумерации страниц].

12. [Столыпин А.Д.] Письма из Западного края // Военный сборник. 1864. Т. 37. № 5. $219-228$.

13. [Столыпин А.Д.] На смерть графа Михаила Николаевича Муравьева // Виленский вестник. 1866. № 184. 1 сентября.

14. [Столыпин А.Д.] Хроника Генриха Латыша, как подспорье к изучению древней истории Северо-Западной Руси // Виленский вестник. 1867. № 107. 14 
сентября.

15. Столыпин А.Д. Краткая история России для народного и солдатского чтения. СПб.: [б. и.], 1869. 112 с.

16. [Столыпин А.Д.: Некролог] // Курьер. 1899. № 319. 18 ноября.

17. С.Ш. [Шолкович С.В.]. Рец.: Историческая таблица Северо-западной части Российской империи, занимаемой губерниями: Виленской, Ковенской и Гродненской // Журнал для родителей и наставников. 1865. № 4. С. 45.

18. [Тютчев Ф.И. Стихотворение на кончину М.Н. Муравьева] // Домашняя беседа. 1866. № 43. С. 995.

19. Театральная новость на новый год // Виленский вестник. 1866. № 3.4 января.

20. Jurkowski R. Pomocnicy Michała Murawiewa. Arkadiusz i Dymitr Stołypinowie i ich działalność w Wilnie w latach 1865-1874 // Echa Przeszłości. 2014. T. 15. P. 93-108.

(с) Комзолова Анна Альфредисовна (amok.1863@mail.ru).

Журнал «Современная наука: актуальные проблемы теории и практики»

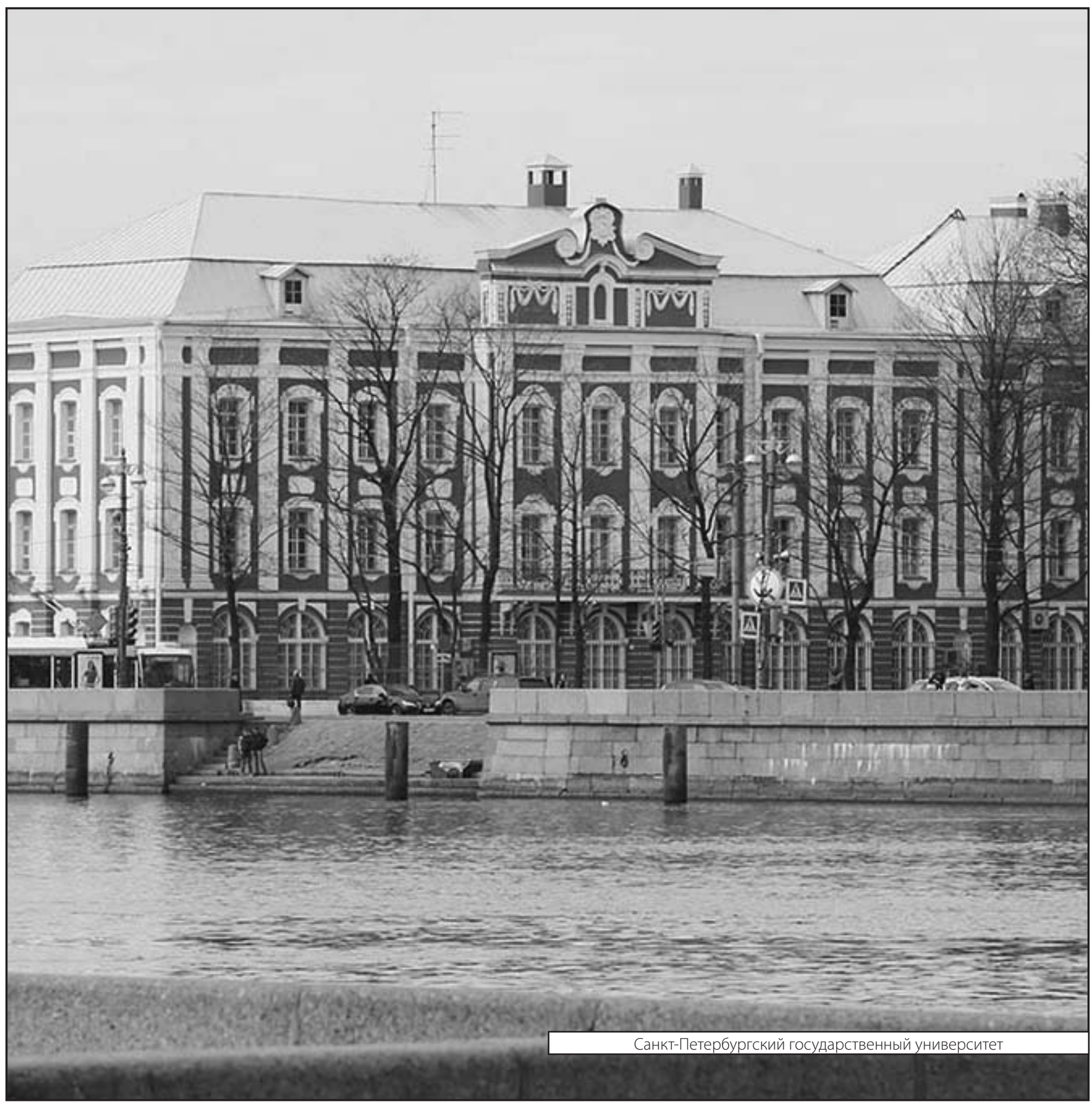

